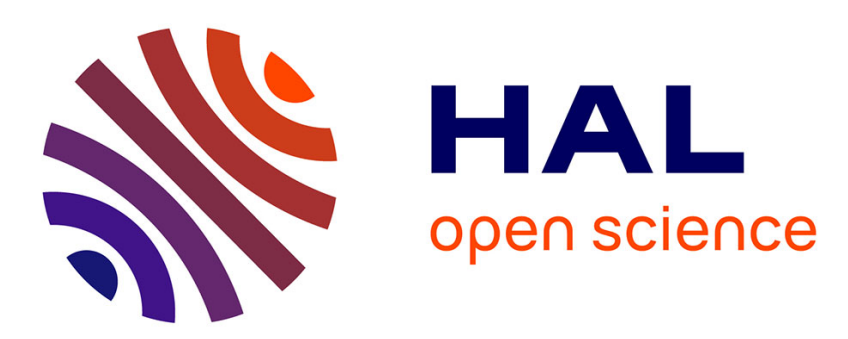

\title{
Construction Work and Wages at the Dergé Printing House in the Eighteenth Century \\ Rémi Chaix
}

\section{To cite this version:}

Rémi Chaix. Construction Work and Wages at the Dergé Printing House in the Eighteenth Century. Cross-Currents: East Asian History and Culture Review, 2016, 5 (2), pp.264-290. 10.1353/ach.2016.0009 . hal-03106476

\section{HAL Id: hal-03106476 https://hal.science/hal-03106476}

Submitted on 11 Jan 2021

HAL is a multi-disciplinary open access archive for the deposit and dissemination of scientific research documents, whether they are published or not. The documents may come from teaching and research institutions in France or abroad, or from public or private research centers.
L'archive ouverte pluridisciplinaire HAL, est destinée au dépôt et à la diffusion de documents scientifiques de niveau recherche, publiés ou non, émanant des établissements d'enseignement et de recherche français ou étrangers, des laboratoires publics ou privés. 


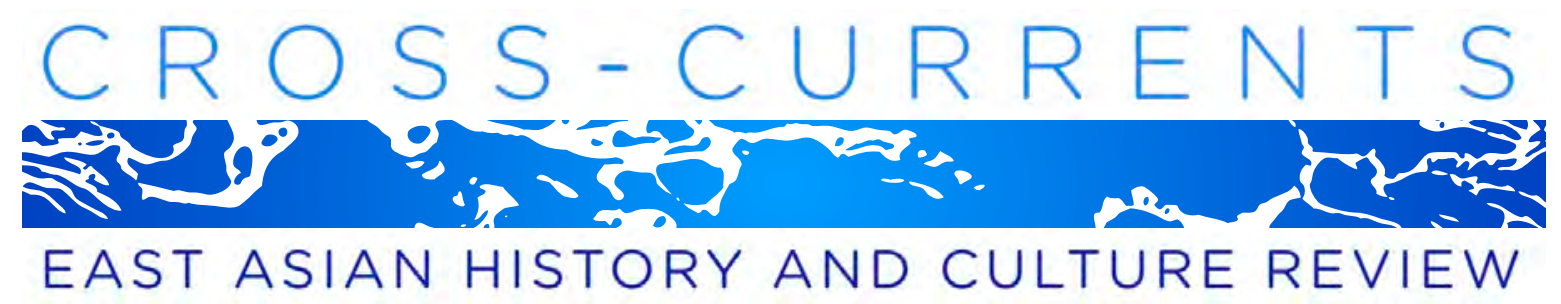

\title{
Construction Work and Wages at the Dergé Printing House in the Eighteenth Century
}

Rémi Chaix, École Pratique des Hautes Études

\begin{abstract}
During the eighteenth century, the powerful Kingdom of Dergé in eastern Tibet became a major political, economic, and religious center that gave birth to one of the most important printing houses in the Tibetan world. Written documentation about the construction of the building and the work performed by numerous artisans allows for a better understanding of the traditional economy in Kham in general, and of wage labor in particular. This article investigates the nature and terms of remuneration for construction and decoration work on the extension to the printing house that was built in 1744-1745. It demonstrates that, in Kham, tea and barley were taken as a reference value to estimate wages and, in so doing, lays out the methodology for comparing these data with those of Central Tibet, where the terms of remuneration were far more complex, including as many as ten different types of goods. This analysis contributes to a better understanding of the role certain goods and trade items played in the economy and lays the groundwork for the history of remuneration in Kham and Tibetan societies at large.
\end{abstract}

Keywords: printing house, Dergé, Kham, Tibet, economy, wages, construction work, decoration work

\section{Introduction}

The history of economic facts, particularly as far as quantitative aspects are concerned, remains an underinvestigated field of research with regard to pre-twentieth-century Tibet. Multiple factors have contributed to this situation: the small number of documents, limited access to them, and the fact that any relevant figures are scattered here and there and are, above all, difficult to interpret. However, the few existing studies concerning Central Tibet (Surkhang 1966; Chapela 1992; Dungkar 1997; Tsarong 1998a and 1998b; Cüppers 2010) show that these data may in fact provide clues as to how to understand social facts in the pre-twentieth-century Tibetan context and how to carry out a more detailed analysis of them. As Dungkar Lozang Trinlé (Dung dkar Blo bzang 'phrin las [1989] 1997) has demonstrated in his pioneering work, ${ }^{1}$ the study of the economy of wood-block printing technology opens a new window onto a segment of the Tibetan 
population that has previously been barely visible in traditional sources and among standard socio-professional categories, such as craftsmen and workers. This historical approach reinforces the image of religious institutions and figures as the force behind the Tibetan traditional economy, but it also investigates, from a new angle, the nature of interactions between religious institutions and lay communities. This article seeks to contribute to this line of research by analyzing figures relating to prices and wages in eighteenth-century Dergé and the way they were estimated using certain types of goods. Trade certainly contributed to the wealth of the Kingdom of Dergé; it also affected the economy of values by making tea one of the main units of measurement and the currency of account.

The vast majority of available sources for this research are not archives and records (such as account books); rather, they include the occasional, more or less accurate and reliable references made by Buddhist scholars in tables of contents related to monuments or editions, biographies, monastic histories, and so on. In legal codes and juridical documents, such as the various shelcé (laws and regulations) or the Shebam chenmo (official government documents), mention is made of the exchange value of major commodities based on their units of measurement. This attests to the fact that the religious figures who authored these documents showed some interest in the cost of things and in economic exchanges (for example, the value of donations) and some willingness to communicate and even promote the wealth they invested in religious activities.

Kham was a relatively wealthy region where substantial economic exchanges between Central Tibet and China took place, especially from the mid-seventeenth century onward, and it was regarded by religious institutions in Central Tibet as an ideal location for raising funds. Unfortunately, few sources exist regarding the economic history of Kham's religious institutions or political entities compared to what is available for Central Tibet. One exception is the Kingdom of Dergé, which enjoyed its heyday during the eighteenth century. Various documents, particularly those relating to the Dergé Printing House (Ch. Dege yinjingyuan; Tib. sDe dge par khang), provide detailed figures for the economic activity of this institution, which rapidly developed during the first half of the eighteenth century to become the largest printing house in the Tibetan world. It was renowned for the diversity and quality of its production and thus no doubt contributed significantly to the reputation and attractiveness of the Kingdom of Dergé. 
In a previous study of the cost of producing wood blocks at the Dergé Printing House during the first half of the eighteenth century (Chaix 2010), I relied on data provided by karchaks (tables of contents) of three canonical collections: the Kangyur, the Sakya Kabum, and the Tengyur editions. These sources from three different authors-Situ Panchen (1700-1774), Tashi Lhündrup (1672-1739), and Zhuchen Tshültrim Rinchen (1697-1774), respectively-make specific mention of the different trades and craftsmen involved in the work, the nature and terms of remuneration, the cost of the different materials, food expenses, and, finally, the total expenditure. The synthesis and analysis of the figures (expressed in units of tea and barley) show that intermediate sums and total sums were not actually reported from bookkeeping sources. Instead, they were calculated from basic figures such as the total number of wood blocks in the edition, wage rates, the number of days worked, and so on. Despite the fact that the amounts quoted by these sources are not totally accurate, their relative consistency led me to believe that the actual costs were not far from these amounts and could be used as a starting point for further studies and estimations. My earlier study also showed that wood-block editions of canonical collections were not only prestigious works produced by the House of Dergé but also part of its policy of developing the new kingdom, which was expected to rival religious centers in Central Tibet. These political and economic developments took place thanks to the strategic position of the kingdom on the main trade route between Sichuan and Central Tibet and the good relations the House maintained with these two powerful centers.

This article sets out to further my preliminary study by investigating the question of wages and the remuneration scale based on figures for the cost of building an extension to the printing house in the 1740s. In Zhuchen's karchak (1748) concerning this building, ${ }^{2}$ the history of the construction work, the description of the religious supports (murals and sculptures), and the wages and expenditures, along with the total cost, are explained in great detail. In what follows, I will briefly describe the early history of the printing house and provide the figures that Zhuchen gives for the cost and wages. I will then analyze and compare these figures with other data compiled from the production of wood blocks for canonical collections and other buildings (the temples of Dokhoma, Sakar, and Yilhung) erected within the Kingdom of Dergé during the same period. Lastly, based on Dungkar Lozang Trinlé's and Christoph Cüppers's studies, I will discuss the possibility of comparing these figures with those for Central Tibet during the late seventeenth and eighteenth centuries. This will allow me to show that a quantitative approach to 
the history of economic facts, and more specifically of wages, is required if we are to understand and assess the credibility of the numerous figures that are scattered here and there in sources other than accounting documents and archives. It will also help to highlight the major role that tea began to play in economic exchanges in Kham from this period on.

\section{The Building of the Printing House and Its Extension}

The official launch of the wood block edition of the Kangyur in mid-1729 (the seventh month of the Earth-Bird Year) by the King of Dergé is generally believed to have coincided with the setting up of the Dergé Printing House (Karma Gyaltsen 2000, 38). However, the early history of the printing house remains unclear, since very few sources are available. The project to create an institution in Dergé that specialized in producing wood blocks and prints was initiated at the beginning of the eighteenth century (Chaix 2010, 91-92) by King Sangyé Tenpa (r. 16751710) and his chaplain Sangyé Phuntsok (1649-1705). In fact, when King Tenpa Tshering (r. 1714-1738) officially launched the project in 1729, several thousand wood blocks for the Kangyur (at least eight thousand, representing a quarter of the total amount) or other texts had already been carved and stored in the Dergé Royal Monastery (Lhündrup Teng).

No contemporaneous document seems to confirm the common assertion that the printing house was built in $1729 .{ }^{3}$ In fact, Ugyen Yeshé writes in 1718 that the 4,700 wood blocks of the Bum edition, later included in the Kangyur, were laid in a place called the parkhang chenmo (lit. "great printing house"), where they underwent a consecration ritual. ${ }^{4}$ We do not know if he was in fact referring to a particular room in Lhündrup Teng Monastery or to a separate building reserved for this purpose, or even if it was where the printing house now stands. Zhuchen, in his karchak about the later extension to the printing house, credits Tenpa Tshering with having opened a printing house (parkhang) with consecrated supports for the Kangyur's wood-block edition (Parkhang karchak [1748] 1974, 137). He later refers to the main building as the "temple of the Kangyur." And lastly, Zhuchen states that the veranda (barkhyam) above the "old temple" (tsuglakhang nyingpa) was used to store wood blocks for the 104 volumes of the Kangyur (almost 33,000 wood blocks) and numerous other sutras, liturgical texts, and commentaries. ${ }^{6}$ In the autobiography he wrote in 1774, Zhuchen mentions the original building twice, once in reference to the year 1743 and once to the year 1745. At the first occurrence (p. 508), he says that 80 measures of tea (jakhordruk) ${ }^{7}$ were taken from the "printing house" (parkhang) to 
finance rituals in the kingdom's main monasteries. At the second occurrence (p. 510), he states that the new temple erected to store the wood blocks for the Tengyur edition was built along the lines of the "old printing house" (parkhang nyingpa). Despite discrepancies about the actual date of construction, these references both seem to confirm that the printing house's first building was a purpose-built temple that was perhaps later converted to store the wood blocks. This oldest temple in the printing house complex (figure 1) is commonly known today as the "Old Temple" or the "Protectors' Chapel" (gönkhang; see Yang 2000, 108).

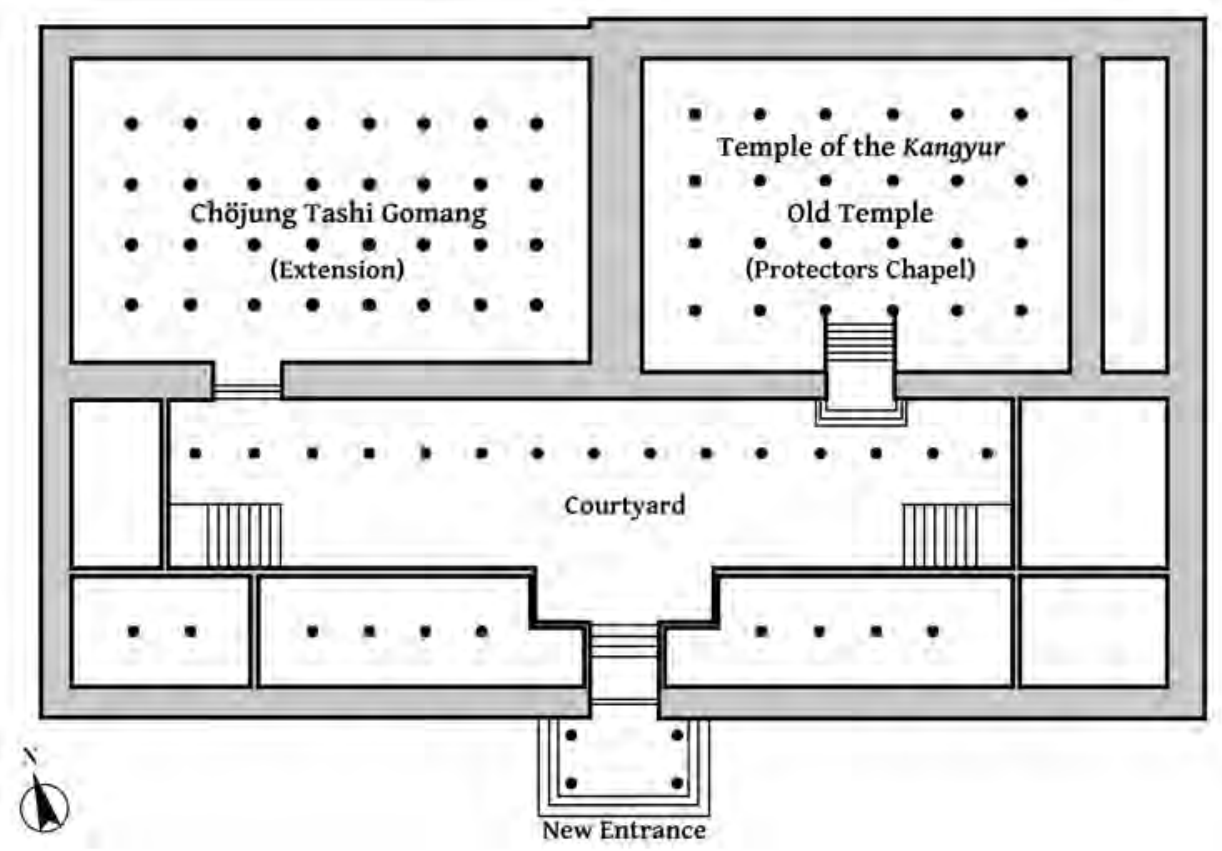

Figure 1. Floor plan of the Dergé Printing House, c. 2000. Source: Adapted from Feng, He, Song, and Wang $(2003,59)$.

No explanation of the choice of the location for the first building (see figure 2) is given in contemporaneous sources. According to recent publications about the printing house (Kandze gönde 1995, 408-409), ${ }^{8}$ oral traditions attribute the choice to King Tenpa Tshering, who relied on a series of auspicious signs. The story goes that the idea of establishing a printing house in Dergé first came to him when, from his window in Nyingön Palace, he saw a group of children building a printing house out of horse dung on a small hump-like hill. However, he thought that he would not be able to collect enough timber to build it. Shortly afterward he received a message from Situ Panchen, who was residing in Paljor Monastery (Situ Panchen's primary place of residence before Palpung was founded in 1727). The message said that he should do 
whatever he had in mind and that he would indeed be able to collect all the timber and other necessary materials. The king realized that this advice might pertain to his printing house project. Meanwhile, so the story goes, in the region of Kutse (in south Dergé on the right bank of the Drichu), a man named Lhawang, who was training in wood-block carving, had a dream and was taught the entire technique in a single night. He was consequently able to carve the Tshedo (Aparimitāyurjñāna-nāma-mahāyāna-sūtra); he decided to offer it to the King of Dergé and set off with the wood blocks loaded on a bull. Three days later, Lhawang arrived at last in the capital. His bull suddenly bucked and all the wood blocks fell to the ground at the very place where the children had erected their small printing house. Interpreting this event as a definite sign, the king took the decision to build the printing house at this auspicious yet unexpected location.

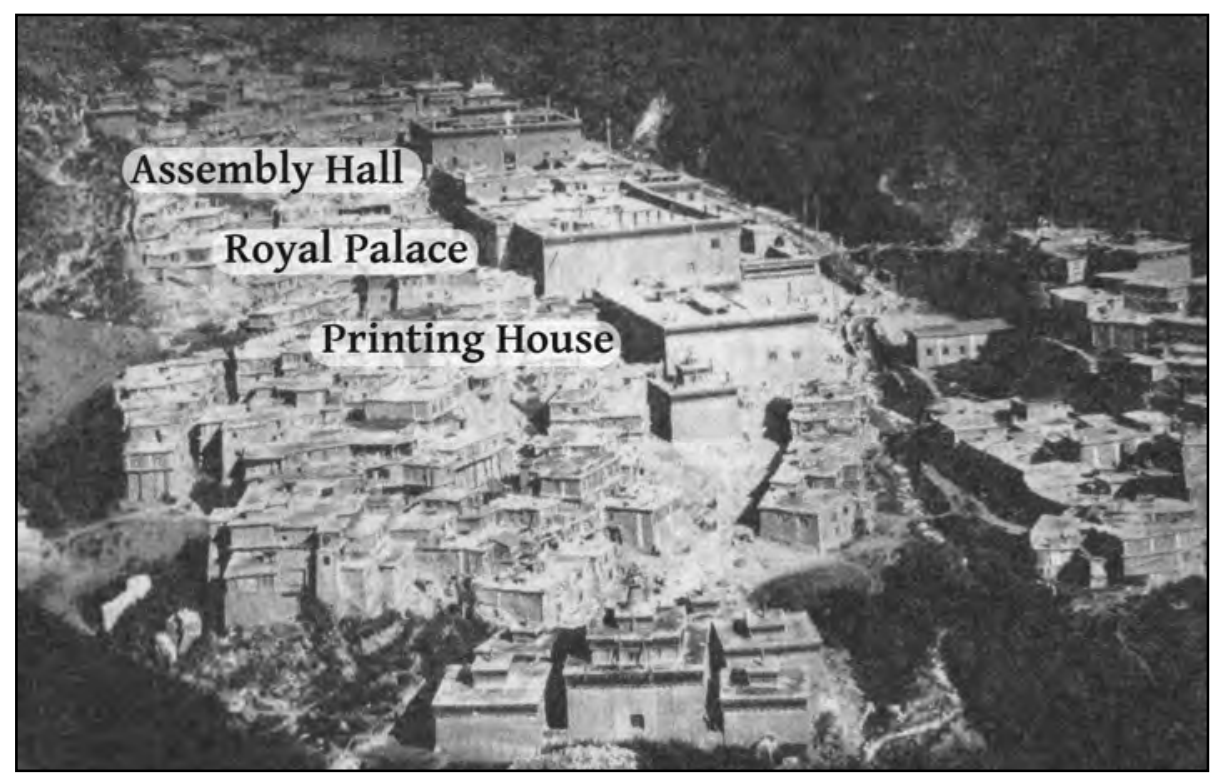

Figure 2. Location of the main buildings of Dergé Gönchen, 1911. Source: Lha lung 'chi med rdo rje (2009).

We can assume that the printing house was built as a separate unit from the main assembly hall and close to the palace because lay workers (who likely included women) contributed to the printing production. It may also be possible that the king did not want the printing house to be within the Sakya Monastery (Lhündrup Teng) compound since his overall project was to include literary works on all Buddhist traditions, even though the printing house managers were chosen from among all the monks in the royal monastery. 
After completion of the Sakya Kabum and the Tengyur wood blocks (about 5,600 and 62,500 wood blocks, respectively) in 1743, the building must have been too small to store them all. The king and the head (tripa) of the royal monastery, Künga Trinlé Gyatso (r. 1738-1751), decided to finance the construction of an extension to the old building on the western side (see figure 1). The project began on the twenty-eighth day of the second month of the Wood-Mouse Year (1744), with rituals to examine and take possession of the site being performed by Palden Chökyong (1702-1760), the former abbot of Ngor and the king's main chaplain, along with fourteen other tantric masters (vajracaryas) (Parkhang karchak [1748] 1974, 138). ${ }^{9}$ The project was supervised by the prime minister (dünadön chenpo), Lhabu Tshering, and the construction work was managed by the head of the printing house, Tshültrim Rabten, and his two assistants.

Once the guidelines had been drawn up, work could start on the foundations. The erection of the building, whose surface area covered forty pillars, required several hundred workers and was completed within two years. These workers included lumberjacks, wood carvers, wall builders, and paid corvée laborers (ulak lalenpa) in charge of transporting and carrying away earth and rocks. ${ }^{10}$ Zhuchen states that during the first stage of construction, the maximum number of workers amounted to more than a thousand. During subsequent stages, their number varied from six hundred to eight hundred, depending on the work involved.

After structural work had been completed, plasterers, religious painters on wood (a master and his apprentices), along with cooks and tea preparers joined the team of workers. Then, about a year later, a group of about eighty religious painters started work on the murals. In the karchak, Zhuchen carefully explains the iconographic programs regarding the wall paintings and the clay sculptures made to decorate the new building (Parkhang karchak [1748] 1974, 165-174). $\mathrm{He}$ also describes in great detail the painters and the schools of art they belonged to (mainly menri, khyenri, and karma gadri). The two head painters were Aphel from Meshö and Lhaga from Karma (Lhateng). The murals in the main temple, representing twenty-nine Buddha fields (shingkham), were done by teams of five painters (Parkhang karchak [1748] 1974, 160). On the outside wall, paintings depicted the lineage of Sakyapa masters along with the main members of the House of Dergé, including the king at the time, Künga Trinlé Gyatso. The entire building and the decoration work were fully completed by the end of the first half of the ninth month of the Fire-Rabbit Year (1747). Zhuchen also mentions that the wood blocks for the 209 volumes of the 
Tengyur were stored on the veranda above the temple, along with those for about seventeen volumes of the biographies of religious figures and those for the Baidurya karpo.

Palden Chökyong, Namkha Palzang, and thirty-three other monks performed the building's consecration ritual (rabné) and gave the temple the name Chöjung Tashi Gomang (lit. "[Temple of the] Many Auspicious Doors of the Origin of the Dharma").

\section{Wages and Cost of Labor}

In the first section of the third part of his karchak, Zhuchen explains how workers were "gratified with offerings."11 He starts by emphasizing that the King of Dergé "was not like some headmen, who, motivated by ambition and a desire for fame, were accustomed to imposing taxes and to forcefully using corvée laborers ${ }^{12}$ for the accomplishment of virtuous activities without even providing food" (Parkhang karchak [1748] 1774, 177). ${ }^{13}$ After quoting sutras about the benefits of generosity and the need to provide religious artists with the appropriate financial compensation, he lists some of the craftsmen and trades in chronological order of their involvement in the construction and decorative work.

Zhuchen then reports that each worker was given thirteen bowls of tea and soup every day, and 1.5 dong of tsampa (roasted barley flour). ${ }^{14}$ According to him, wages (layön), calculated as measures of tea, were handed out according to what was needed, in the form of different kinds of goods: tea, tobacco, cotton, yawa (possibly a kind of fabric), silk, brocade, various kinds of woolen cloth and leather goods, horses and cattle, different types of clothing, cast bronze pots, and other essential utensils. He then gives a list of wages according to each category of worker and based on one weighed measure of tea (barkhak) for every $x$ days of work, as follows:

\begin{tabular}{|l|l|}
\hline Category of Worker & Wage (Per Person) \\
\hline paid corvée laborer ('u lag gla len) & 1 barkhak/12 days \\
\hline assistant carpenter (shing mkhan mchan ma) & 1 barkhak/12 days \\
\hline wall builder (gyang bzo ba) & 1 barkhak/12 days \\
\hline plasterer (zhal mkhan) & 1 barkhak/12 days \\
\hline head carpenter (shing mkhan dpon po) & 1 barkhak/9 days \\
\hline pigment grinder (tshon 'dur ba) & 1 barkhak/8 days \\
\hline one who applies color (tshon 'gyed pa) & 1 barkhak/7 days \\
\hline
\end{tabular}




\begin{tabular}{|l|l|}
\hline assistant painter (lha ris pa mchan $m a)$ & 1 barkhak / 6 days \\
\hline gilder $($ gser gsol pa) & 1 barkhak / 6 days \\
\hline gold-leaf maker (?) (gser shog pa) & 1 barkhak / $\mathbf{6}$ days \\
\hline color preparer (tshon sbyor ba) & 1 barkhak / 4 days \\
\hline head painter (lha dpon) & 1 barkhak / 4 days \\
\hline
\end{tabular}

Figure 3. Table of wages for the printing house extension. Source: Parkhang karchak ([1748] $1774,179)$

The number of workers in each category is not mentioned, except for carpenters (fifty persons) and painters (eighty persons). The total expenditure for extending the printing house, including all the wages, regular religious celebrations (tönmo), the cost of the gold, the pigments, and all necessary wares, amounted to 3,588 jakhordruk, the reference unit for measuring tea. ${ }^{15}$

\section{Remuneration Scale in Dergé}

It proved a challenging task to analyze these figures based only on limited and incomplete information provided by Zhuchen. Assuming that Zhuchen and the editors of his Collected Works made no mistake or amendment in reporting the data collected by bookkeepers, this list of wages (figure 3) reveals that paid corvée laborers were given the same amount as assistant carpenters, wall builders, and plasterers and, most likely, that paid corvée laborers were considered equal to the aforementioned categories of worker. The standardized way the wages are presented allows us to readily estimate the wage differences within this project. For example, a paid corvée laborer earned three times less than a head painter or a color preparer and half what an assistant painter or a gilder earned. Without knowing the actual number of workers in each category, the number of days they worked, or the total amount spent on each category of workers, only a simple classification based on the remuneration scale can be made using these figures.

In order to estimate whether Zhuchen's figures are reliable, we need to look at other textual sources concerning building or decoration work in the Kingdom of Dergé during the same period. Although the information is scattered here and there in several karchaks relating to temples and in biographies, it may provide more insight into the wages in Dergé during the eighteenth century.

Another reference to remuneration payments can be found in Situ Panchen's autobiography, in which he mentions that in 1729 each painter who contributed to the murals of 
the assembly hall (dukhang) in Palpung was provided with one barkhak of tea every four days. ${ }^{16}$ This is exactly the same wage that a head painter at the printing house received in 1747.

To assess the credibility of the global cost of the construction and to find out whether it was overestimated to magnify the patron's generosity, let us take two figures provided by Palden Chökyong (Paldan chökyong rangnam, [176?] 1974, e 1:399) and Zhuchen (Lhagyel karchak [1764] 1973, 440), respectively. The first is for the three-story temple of Dokhoma, 16 pillars in size, which cost 2,735 jakhordruk in 1744; the second is for the main temple and the protector chapel of Lhagyel (Yilhung), built in 1764, which cost 2,733.25 jakhordruk. Compared to these figures, the cost of the extension (40 pillars) of the printing house, which totaled 3,588 jakhordruk, appears to be a consistent and reliable figure.

One major source of comparison that deserves our attention is again provided by Zhuchen in the karchak about the new temple at Sakar Monastery, which was built in 1751-1752. In this text written in 1755, a section is devoted to the cost and wages invested in construction and decoration work. Zhuchen estimates the total cost of the temple (including the destruction of the old building but not taking into account the consecration rituals) at 2,484.65 jakhordruk $(2,484.5$ jakhordruk, 0.5 barkhak, and 1/9 of a barkhak). ${ }^{17}$

In this case, contrary to the building of the extension to the printing house, corvée laborers were not paid and were recruited in the districts (deshok) between Tsekhok (?) and Kashi Monastery. Their number varied between two hundred and three hundred. Each laborer received only ten bowls of soup and tea every day, and the tea, butter and tsampa were provided by their own districts. Paid workers, such as carpenters, carvers, and blacksmiths - thirty persons in all - were given twenty bowls of soup and tea every day, along with one dre of tsampa, one pancake (bagsek), and "meat and beer" (shachang). For the first year (1751), Zhuchen estimates the cost of food and drinks at 8 jakhordruk per day and at 1,504 jakhordruk for 188 working days.

Zhuchen provides information on different categories of craftsmen and workers involved in the project (lumberjacks, blacksmiths, carpenters, masons, clay sculptors, painters, gold-leaf makers, and tailors, among others), as well as the name of their headmen and the total number of persons in almost every category. He also specifies that the work was done in two phases, providing the total number of days worked, which allows us to understand how some of the total costs were obtained: during the first year (1751) the destruction of the old building and structural 
work for the new temple were completed within a period of 188 days; in the second year, the religious sculptures and paintings, along with embellishments, were completed within 189 days, on the twenty-ninth day of the ninth month of the Water-Monkey Year (1752). Unfortunately, Zhuchen does not mention all the wages for each category but lists only the main ones. Even though wages were paid in various kinds of goods, they were fixed according to a standard unit of tea (barkhak) and its market price (rinthang).

\begin{tabular}{|l|l|l|l|}
\hline Category of Worker & $\begin{array}{l}\text { Number of } \\
\text { Persons }\end{array}$ & Wage (Per Person) & $\begin{array}{l}\text { Total Cost in } \\
\text { Jakhordruk }\end{array}$ \\
\hline corvée laborer & $200-300$ & $\begin{array}{l}\text { only food (10 bowls of soup } \\
\text { and tea per day) }\end{array}$ & \\
\hline head carpenter & 1 & 68 barkhak / 2 years & 17 \\
\hline best (rab) carpenter & 13 & 1 barkhak / 6 days & 100.58 \\
\hline average ('bring) carpenter & 10 & 1 barkhak / 7 days & 40.43 \\
\hline assistant carpenter & 7 & 1 barkhak / days & 36.61 \\
\hline mason & 4 & 9 barkhak & 2.25 \\
\hline head painter & 3 & $?$ & 205 \\
\hline painter & 20 & 1 barkhak / 5 days & 178.5 \\
\hline assistant painter & 21 & 1 barkhak / 6 days & 161 \\
\hline artist's assistant (?) & 23 & 1 barkhak / 8 days & \\
\hline
\end{tabular}

Figure 4. Table of wages for Sakar Temple. Source: Sakar karchak ([1755] 1974, 272-274).

\section{A Comparative Assessment of Wages}

In order to evaluate and compare wages between the different projects in Dergé and elsewhere in the Tibetan cultural area, they first have to be converted on a daily basis into a shared unit of measurement that could be applied to the value of standard goods. Taking tea as the standard merchandise poses a problem because its value rose significantly west of Dartsedo. Gold or silver are often taken as reference values, but their price has fluctuated so much since the seventeenth century that it would make any comparison or conversion far from accurate (Boulnois 1983, 139-146). Although barley seems to be a more obvious choice because it was the Tibetans' staple food, the unit volume used to measure it, nekhel, appears to differ from one region to another (see Dung dkar [1989] 1997, 432). Even though we do not know the exact 
difference in volume between the official nekhel (kharu nekhel) in Central Tibet and its regional variants, nekhel seems to be the least problematic unit for assessing wages in the Tibetan world.

Dungkar ([1989] 1997, 425) was able to outline a rough history of basic wages in Central Tibet since the thirteenth century using figures taken from karchaks and legal texts. According to his findings, under the Sakya and Phagmodru regimes (mid-thirteenth to mid-fifteenth century), the daily wage for "stone, wood, and iron" work amounted to 0.1 nekhel ( 2 dre). During the reign of Tsang Depas (mid-sixteenth to mid-seventeenth century), skilled workers were paid 0.166 nekhel (3 dre, 2 phul) and standard workers received 0.1 nekhel. Under Desi Sangye Gyatso's rule (1682-1705), the highest daily wage was 0.333 nekhel (6 dre, 4 phul) and the lowest 0.166 nekhel. In his biography of the Fifth Dalai Lama, Sangye Gyatso recorded a similar figure for a Nepalese stone chiseler who produced a low-relief stupa on a rock at Gongkar (in 1681) and was paid a daily wage of 0.422 nekhel (16.875 nekhel for forty days of work) (Dukula Gözang [1690] 2009, 8:273).

As we have seen, wages in Dergé were fixed according to standard units of tea (barkhak and jakhordruk), so for the purpose of our comparison we need to establish the conversion into nekhel, the volume unit of barley. Fortunately, Zhuchen gives the total cost of the Tengyur woodblock edition in units of barley and tea (Tengyur karchak [1744] 1985, 578), which enables us to calculate the exchange rate in Dergé in 1744: one jakhordruk (tea) was worth 20 nekhel (barley). Using this figure, we can draw up a provisional table of the wages (in descending order) that applied in mid-eighteenth-century Dergé (figure 5), and then compare them with Dungkar's figures. In addition to the two building projects, it is worth adding the printing house wages for editing and carving work, as they are also provided by Zhuchen (Chaix 2010, 97-98).

This tentative list immediately reveals certain inconsistencies. For example, the remuneration of the head carpenter (shingkhan ponpo) working on the extension project appears to be very low compared to that of an average carpenter working on the Sakar project (22 percent less). But above all, it shows that wages for editing and carving work are inconsistent with those for construction and decoration work. It is extremely unlikely that a reviser would have been paid less than an assistant carpenter or a paid corvée laborer. While the figures for revisers, line tracers, and paper makers seem to be coherent with Dungkar's, wages for construction and decoration work appear to be high: an assistant carpenter was paid between 1.25 and 1.67 times more than the highest daily wage for construction workers in Central Tibet. 


\begin{tabular}{|l|l|l|l|}
\hline Category of Worker & $\begin{array}{l}\text { Wage for } \\
\text { Editing and } \\
\text { Carving Work } \\
\mathbf{( 1 7 3 7 - 1 7 4 4 )}\end{array}$ & $\begin{array}{l}\text { Wage for the } \\
\text { Extension to the } \\
\text { Printing House } \\
\mathbf{( 1 7 4 4 - 1 7 4 7 )}\end{array}$ & $\begin{array}{l}\text { Wage for Sakar } \\
\text { Temple } \\
\mathbf{( 1 7 5 1 - 1 7 5 2 )}\end{array}$ \\
\hline head painter & & 1.25 & \\
\hline color preparer & & 1.25 & 1 \\
\hline painter & & & 0.833 \\
\hline assistant painter & & 0.833 & 0.833 \\
\hline best carpenter & & & \\
\hline gilder & & 0.833 & \\
\hline gold-leaf maker & & 0.833 & 0.714 \\
\hline one who applies color & & 0.714 & 340 per $x$ days \\
\hline average carpenter & & & \\
\hline pigment grinder & & 0.625 & 0.555 \\
\hline head carpenter & & 0.555 & 45 per $x$ days \\
\hline head reviser & 0.55 & & \\
\hline assistant carpenter & & 0.417 & \\
\hline wall builder & & 0.417 & \\
\hline plasterer & & 0.417 & \\
\hline head reviser's assistant & 0.35 & & \\
\hline reviser & 0.325 & & \\
\hline print reviser & 0.325 & & \\
\hline line tracer & 0.25 & & \\
\hline paper maker & 0.25 & & \\
\hline & & & \\
\hline & & & \\
\hline
\end{tabular}

Figure 5. Tentative table of wages (in nekhel per day) in the Kingdom of Dergé during the eighteenth century. Source: Chaix (2010, 97-98).

There are several explanations for these inconsistencies. First, the exchange rate given by Zhuchen may not be accurate, and 1 jakhordruk might have cost more than 20 nekhel. We should also consider the fact that the figures given by Zhuchen for construction work are not the salary paid to the worker but worker's cost to the employer, including his food, drinks, and wage. We may then assume that a paid corvée laborer's wage was in fact his provision in food and drinks (0.417 nekhel/day). Thus, we can subtract this amount from the wage in each category and obtain other tentative amounts for: head painter and color preparer (0.833); painter (0.583); head reviser (0.55); assistant painter, best carpenter, gilder, and gold-leaf maker (0.416); head reviser's assistant (0.35); reviser and print reviser (0.325); one who applies color and average carpenter (0.297); line tracer and paper maker (0.25); pigment grinder (0.208); and assistant carpenter (0.138). Following this hypothesis, we end up with an apparently more consistent list, even though the head reviser's wage still seems low compared to the head painter's and to the amount 
paid to the worker who prepares color. These figures also mesh well with those in Shebam chenmo that Cüppers $(2010,125)$ noted regarding a 114-volume Kangyur edition that was made on indigo-colored paper (serchö) in 1683. The daily wages for this project were as follows: 0.5 nekhel for an icon painter and a clay sculptor, 0.333 for a varnisher, 0.25 for a tailor and a paper dyer, 0.2 for a smith, 0.333 for a skilled (khepa) woodworker, and 0.2 for a regular (zhen sa?) woodworker.

To further assess whether the figures for wages in Dergé are accurate and reliable, it might be interesting to compare them with other similar figures for equivalent projects in Central Tibet. Unfortunately, such a comparison faces the problem of the different units of measurement used and the difficulty in establishing an exchange rate. For instance, in the karchak (1697) for the tomb of the Fifth Dalai Lama, Desi Sangye Gyatso (Chödong [1697] 1990, 282-284) gives a list of the monthly wages (daphok) that construction and decoration workers were paid. Each wage mentioned is based on a certain quantity of different items: grain, sheep carcasses, sheep's heads for making soup (thugdor), salt, oil, tea, butter, cheese, ko tshil (fat with the hide still on), or sheep. To give just a few examples, every month a head carpenter (shingzo uchen) was paid: 10 nekhel, 1 carcass, 2 sheep's heads, 1 dre of salt, 1 dre of oil, 1 nyag of tea, and 2.5 nyag of butter. An ordinary carpenter (shingzo kyuma) was paid: 5.5 nekhel, 0.5 carcass, 1 sheep's head, 1 dre of salt, 1 dre of oil, 0.5 nyag of tea, and 1.25 nyag of butter.

The daily wage in terms of a volume of barley amounted to 0.333 nekhel for a skilled carpenter and 0.183 nekhel for an ordinary carpenter. However, without knowing the exact exchange rate in barley for any other item, we cannot calculate the exact remuneration. Wages for editing and carving work in the wood-block edition of the Kangyur of Narthang (1731) were also given following this "template" for the provision of items (see Dungkar [1989] 1997, 431432). These terms of remuneration had already been attested to by the end of the fifteenth century (Caumanns 2013, 74), but our current knowledge of exchange rates makes it difficult to establish a remuneration scale for the same project and almost impossible to make any accurate comparison with wages in Dergé.

\section{Conclusion}

This article set out to contribute to the study of the economic aspects of the Dergé Printing House during the eighteenth century. The main textual source relevant to the extension 
to the building provides us with detailed figures that, when compared with other sources about construction work during the same period and in the same region, are crucial to our understanding of the terms of remuneration for construction and decoration work in Dergé.

In all cases, the calculation of wages is facilitated by the use of a single measuring unit (tea), and provides an opportunity to draw up a simple remuneration scale for construction and decoration work. It notably shows that painters, a class that was well looked upon, were particularly well paid compared to construction workers. But it also highlights the need to find reliable documents that give accurate exchange rates to compare these figures with those mentioned using other units of measure. This is crucial when comparing construction and decoration workers' wages with those of workers in charge of editing and carving. My hypothesis was that the former's wages in fact amounted to the overall cost for the employer, including the provision of items for a worker and their remuneration, while the latter's wages only represented the payment. After deducting the approximate amount for provisions (thirteen bowls of soup and tea per day and a small amount of tsampa), I obtained what seems to be a more accurate and realistic remuneration scale, which remains to be confirmed by further comparative work.

The fact that we have also discovered in different documents the cost of building four temples inside the kingdom over a period of twenty years (1744-1764) enables us to assume that the amounts given in each source are likely to be accurate and can be taken as a reference to estimate the expenditure for other buildings erected over that period. Of course, many questions are pending, and further investigation is therefore necessary. For example, all of this construction work leads us to surmise that the Kingdom of Dergé was relatively prosperous, yet we have no idea of the percentage of this expenditure in the annual budget of the House of Dergé.

In order to determine a benchmark against which we can compare our figures for Dergé, given the lack of further information on eighteenth-century Kham, I looked at the information provided by Desi Sangye Gyatso about the construction of the Red Palace of the Potala and the Fifth Dalai Lama's mausoleum, along with the karchak of the wood-block edition of the Kangyur patronized by Pholané in the 1730s. Although Dergé's investments were on a very different scale than Desi's (the building of the Red Palace and the mausoleum cost almost three hundred times more than the extension to the printing house), I came upon some interesting features concerning the terms of remuneration. 
Most importantly, in eighteenth-century sources from the Kingdom of Dergé, it appears that only two types of goods - tea and barley_-were taken as a reference value to estimate the wages of construction and decoration workers, and the remuneration of monks. However, Central Tibet ( $\ddot{U}$ and Tsang) sources dating from the mid-seventeenth to the mid-eighteenth century show far more complex terms of remuneration, including as many as ten different types of goods (mostly provisions) for the monthly wage of one category of craftsmen. Though there existed a system of equivalence between several types of merchandise (with barley and silver often used as a reference value), no specie-based currency had really emerged as a standard value for prices and wages by the mid-eighteenth century.

This difference may suggest merely that Kham had a more developed market economy ${ }^{18}$ than Central Tibet. The two goods used as reference values (barley and tea) showed sufficient stability on the local market to be used for wages and remuneration, establishing a system of equivalence that, in spite of an apparently stronger state control of the economy by the Ganden Phodrang government, was not achieved to the same extent in Central Tibet. In Kham, the market allowed for payments to be made in barley and tea, even though their price was not the same everywhere in the region; indeed, they were cheaper in Dartsedo than in Chamdo, because they were locally easily convertible with less risk of any loss in value. This major difference also makes any accurate comparison between the wages in these two regions almost impossible until more precise figures about exchange rates between goods (salt, butter, oil, sheep carcasses, tea, etc.) are available for the same period of history.

As I have managed to show in the context of eighteenth-century Dergé, these economic figures for prices, wages, and measuring units are crucial elements for documenting the history of trades and craftsmen, for understanding the social history of a large section of the Tibetan population that generally "escaped the historian's net" (Ramble, Schwieger, and Travers 2013), and for shedding light on some of the complex economic ties that existed between religious institutions and laypeople. On receiving donations and taxes from laypeople, religious institutions in return played a major role in employing local manpower in construction and decoration work, even if corvée labor (ulak) could also be used by landlords to sponsor these activities.

Armed with a better understanding of these facts and figures, we can hope to establish a history of remuneration and a precise remuneration scale that will surely contribute to 
documenting the socioeconomic hierarchy in the history of Kham societies and of other Tibetan cultural areas. More textual sources (mainly biographies, karchaks, legal documents, and archives) will have to be examined to draw up a comprehensive history of prices and wages in Kham and more broadly in the Tibetan world. This huge task needs to be undertaken on a large scale, particularly regarding the precise value of each measuring unit and the exchange rates among them. It is to be hoped that doing so will provide reliable figures for comparison and will allow for a more pertinent analysis of all economic data, such as donations, gifts, taxes, and fines, among others, which are generally scattered here and there in Tibetan documents.

Rémi Chaix is a PhD candidate at the E.P.H.E. (École Pratique des Hautes Études), 4th section, and is affiliated with the Center for Himalayan Studies (C.N.R.S., Villejuif). This essay was composed within the framework of the project titled "Territories, Communities, and Exchanges in the Kham Sino-Tibetan Borderlands" (Starting Grant no. 283 870), financed by the European Research Council (ERC). The author would like to thank the two anonymous Cross-Currents reviewers whose constructive comments helped improve this essay. He is grateful to Dr. Kunsang Namgyal-Lama and Dr. Stéphane Gros for their insightful and constructive comments. He also expresses his gratitude to Bernadette Sellers for her English editing and for improving the essay's style.

\section{Glossary of Tibetan Terms}

\begin{tabular}{|l|l|}
\hline In-Text Vocabulary & Tibetan Transliteration \\
\hline bagsek & bag sreg \\
\hline Baidurya karpo & Baidurya dkar po \\
\hline barkhak & bar khag \\
\hline Chamdo & Chab mdo \\
\hline Chöjung Tashi Gomang & Chos 'byung bkra shis sgo mang \\
\hline Choné & Co ne \\
\hline daphok & zla phogs \\
\hline Dartsedo & Dar rtse mdo \\
\hline Dergé & sDe dge \\
\hline Dergé Gonchen & sDe dge dgon chen \\
\hline deshok & sde shogs \\
\hline Desi Sangye Gyatso & sDe srid Sangs rgyas rgya mtsho \\
\hline Dokhoma & rDo kho ma \\
\hline dong & 'dong \\
\hline dre & bre \\
\hline dünadön chenpo & $m$ dun na don chen po \\
\hline dukhang & 'du khang \\
\hline Dungkar Lozang Trinlé & Dung dkar blo bzang phrin las \\
\hline
\end{tabular}




\begin{tabular}{|c|c|}
\hline Dzomthok & 'Dzoms thog \\
\hline jakhordruk & ja 'khor drug \\
\hline japobtse & ja spob rtse \\
\hline Kangyur & bKa' 'gyur \\
\hline karchak & dkar chag \\
\hline karma gadri & karma sgar bris \\
\hline Kashi & Ka bzhi \\
\hline kharu nekhel & mkhar ru'i nas khal \\
\hline khel & Khal \\
\hline khepa & mkhas pa \\
\hline khyenri & mkhyen ris \\
\hline Künga Trinlé Gyatso & Kun dga' 'phrin las rgya mtsho \\
\hline Kutse & sKu tshe \\
\hline Kyirong & sKyid rong \\
\hline layön & gla yon \\
\hline Lhabu Tshering & 1Ha bu tshe ring \\
\hline Lhateng & 1Ha steng \\
\hline Lhawang & 1Ha dbang \\
\hline Lhündrup Teng & 1Hun grub steng \\
\hline menri & sman ris \\
\hline Meshö & sMad (rme) shod \\
\hline Namkha Palzang & Nam mkha' dpal bzang \\
\hline nekhel & nas khal \\
\hline Ngor Ewam Chöden & Ngor e waM chos ldan \\
\hline Ölga & 'Ol dga' \\
\hline Palden Chökyong & dPal ldan chos skyong \\
\hline Palpung & dPal spungs \\
\hline Pholané & Pho lha nas \\
\hline Phagmodru & Phag mo gru \\
\hline rabné & rab gnas \\
\hline rinthang & rin thang \\
\hline Sakar & Sa dkar \\
\hline Sakya & Sa skya \\
\hline Sakya kabum & Sa skya bka' 'bum \\
\hline Sakyapa & Sa skya pa \\
\hline Sangyé Phuntsok & Sangs rgyas phun tshogs \\
\hline Sangyé Tenpa & Sangs rgyas bstan pa \\
\hline serchö & gser chos \\
\hline sersang & gser srang \\
\hline shachang & sha chang \\
\hline Shebam chenmo & She bam chen mo \\
\hline shelcé & Zhal lce \\
\hline shingkham & zhing khams \\
\hline shingkhan ponpo & shing mkhan dpon po \\
\hline shingzo kyuma & shing bzo dkyus ma \\
\hline
\end{tabular}




\begin{tabular}{|l|l|}
\hline shingzo uchen & shing bzo dbu chen \\
\hline sho & zho \\
\hline Situ Panchen & Si tu paN chen \\
\hline Tashi Lhündrup & bKra shis lhun grub \\
\hline Tengyur & bsTan 'gyur \\
\hline Tenpa Tshering & bsTan pa tshe ring \\
\hline thugdor & thug sdor \\
\hline tönmo & ston mo \\
\hline tsampa & rtsam pa \\
\hline Tsang & gTsang \\
\hline Tsekhok & rTse khog \\
\hline Tshültrim Rabten & Tshul khrims rab brtan \\
\hline tripa & khri pa \\
\hline Ü & dBus \\
\hline Ugyen Yeshé & U rgyan ye shes \\
\hline ulak & 'u lag \\
\hline ulak lalenpa & 'u lag gla len pa \\
\hline yawa & ya ba \\
\hline Yering & Ye ring \\
\hline Yilhung & Yid lhung \\
\hline Zhuchen Tshültrim Rinchen & Zhu chen Tshul khrims rin chen \\
\hline & \\
\hline
\end{tabular}

\section{Notes}

1 This study was recently translated by Tsering Dhundup Gonkatsang; see Dungkar (2016).

2 Parkhang karchak is titled: "gTsug lag khang chos 'byung bkra shis sgo mangs rten dang brten pa ji ltar bskrun pa las brtsams pa'i gleng ba bdud rtsi'i rlabs phreng" [An account of the construction of the temple named Tashi Gomang: The auspicious many-doored source of the Dharma and its sacred objects: Waves of nectar]. Cynthia Col gives a very approximate translation of the text in the appendix to her PhD dissertation $(2009,360$ 536).

3 As far as we know, there is no mention of it being built at this date either in the Kangyur karchak ([1733] 1989) or in the biographies of Tashi Lhündrup (main chaplain of the House of Dergé between 1728 and 1739), Situ Panchen, or Zhuchen.

4 This is mentioned in the karchak of the Bum (Aștasāhasrikā prajñāpāramitā sütra) edition, written in 1718 by Ugyen Yeshé (Bum karchak 1718, f.21b).

$5 \quad$ Parkhang karchak ([1748] 1974, 172): "bka' 'gyur ro 'tshal gyi gtsug lag khang." Zhuchen also refers to the existence of a separate table of contents, which mentions the deities (whether statues or painted) that the building housed.

$6 \quad$ Parkhang karchak ([1748] 1974, 175): "gtsug lag khang rnying pa'i steng gi bar khyams kun tu rgyal gsung 'gyur ro 'tshal gyi phyi mo glegs bam brgya dang bzhi/ gzhan yang mdo sna dang 'don chog rnam bshad sogs kyi shin tu mang bar bzhugs/." 
Jakhordruk (also japobtse) is a unit of measurement for weighing tea, with bagchen (also barkhag or bag, 1/4) and bagchung (1/16) as its subunits. One jakhordruk was packed in a long bamboo basket and was either made up of four bagchens or sixteen bagchungs. According to Father Desgodins (quoted by Rockhill 1891, 278-280), tea bricks (bagchen or bagchung?) were of different weights (between 2.5 and 5.5 pounds) depending on their quality. Our knowledge of jakhordruk in the eighteenth century does not enable us to convert these units of measurement into our conventional weight system. On tea trade between Sichuan and Tibet, see Booz (2011). In this article, I refer to barkhag because it is the term generally used (with bag) in the sources.

8 Cynthia Col $(2009,75-77)$ gives an approximate translation of this passage.

9 The rituals performed were sa gzhi btag pa, sa chog, and sa gter bzhug pa.

10 The category of workers called "paid corvée laborers" (ulak lalenpa) by Zhuchen is ambiguous because it is not clear what differentiated them from other workers and whether their paid corvée labor was deducted from the number of days of mandatory labor.

11 Parkhang karchak ([1748] 1974, 177-180): "yon gyis mnyes par bya."

12 In a Tibetan traditional context, mandatory corvée labor (ulak) for a certain number of days a year was owed by taxpayer households for construction work and transportation, among other tasks; for this labor, the landlord provided no salary or even food. See Goldstein $(1971,10)$.

13 The underlying idea is that the merits gained by the religious activity do not benefit the one who present himself as the "sponsor" but, in fact, the corvée laborer. This explains why Zhuchen emphasized that corvée laborers received wages for their contribution to the project.

14 It is not clear to me whether this statement is valid for the whole project or only for the last phase of work. A dong is a subunit of khel for measuring volume that was used in Dergé and other parts of Kham. Ten dong equaled one sho and four sho equaled a khel (see Dung dkar [1989] 1997, 432). Several authors had already given an approximate weight for Lhasa's official grain volume unit (gshor khal): between 27 and 33 pounds (Bell 1928, 84; Surkhang 1966, 18). Yet we know that, depending on regional features (Tsang and Kham), a khel of grain ('bru khal) may not have been of equal value and we do not know the volume of one khel in eighteenth-century Kham.

15 It is worth noting here that Zhuchen also "predicted" that the total cost of the extension to the printing house would amount to "around 3,600 jakhordruk"; this can be found in the karchak of the Tengyur wood block edition ([1744] 1985, 579) which, as indicated by the colophon, was written in the seventh month of the Wood-Mouse Year (1744) — only five months after building work started! It is probably a post-1747 addition.

16 Situ rangnam ([1774] 1969, 147): “'du khang sdeb bris grub nas lha bris pa rnams la yon nyin ma bzhi rer dngos ja bag re'i 'bab sogs kyi dgyes nges pa phul te."

17 Zhuchen even gives some details of specific costs: 30 jakhordruk for cutting and transporting timber, 35 jakhordruk for preliminary rituals, 150 jakhordruk for pigments, and 26 sersang (ounces) of gold, among others. It would seem that while compiling this data, at least part of the text on the wages of the head clay sculptors was truncated by the editors (Sakar karchak [1755] 1974, 274). 
18 I here refer to market economy as finely described, in the European context, by Fernand Braudel (1986).

\section{References}

$\underline{\text { Tibetan Sources }}$

Bum karchak: U rgyan ye shes. 1718. Sher phyin stong phrag brgya pa rnam par spel ba'i phyi mor bsgrubs pa'i rab tu byed pa/ mthong na mngon par dga' ba. sDe dge dgon chen: sDe dge par khang.

Chödong: sDe srid Sangs rgyas rgya mtsho. (1697) 1990. mChod sdong 'dzam gling rgyan gcig rten gtsug lag khang dang bcas pa'i dkar chag thar gling rgya mtshor bgrod pa'i gru rdzings byin rlabs kyi bang mdzod. Lhasa: Bod ljongs mi dmangs dpe skrun khang.

Dukula Gözang: sDe srid Sangs rgyas rgya mtsho. (1690) 2009. Drin can rtsa ba'i bla ma ngag dbang blo bzang rgya mtsho'i thun mong phyi'i rnam thar du kU la'i gos bzang, in rGyal dbang lnga pa ngag dbang blo bzang rgya mtsho'i gsung 'bum. Vols. 8-10. Beijing: Krung go'i bod rig pa dpe skrun khang.

Kandze gönde: Anonymous. 1995. Khams phyogs dkar mdzes khul gyi dgon sde so so'i lo rgyus gsal bar bshad pa nang bstan gsal ba'i me long zhes bylag khang chos 'byung bkra a ba bzhugs/ deb dang po. Lhasa: Krung go'i bod kyi shes rig dpe skrun khang.

Kangyur karchak: Si tu pạ chen. (1733) 1989. sDe dge'i bka' 'gyur dkar chag. Chengdu: Si khron mi rigs dpe skrun khang.

Lhagyel karchak: Zhu chen Tshul khrims rin chen (1764) 1973. "1Ha rgyal srang gi chos sde srid gsum dge legs yongs 'du'i gtsug lag khang rten dang brten par bcas pa bskrun pa las 'phros pa'i 'bel gtam bkra shis 'khyil pa'i sgra dbyangs.' In The Collected Writings on Buddhist Philosophy, Liturgy, and Ritual of Zhuchen, edited by Jamyang Norbu, 6:405-465. New Delhi: Jamyang Norbu.

Palden chökyong rangnam: dPal ldan chos skyong. (176?) 1974. Ngor mkhan chen dpal ldan chos skyong zhabs kyi rnam thar sna tshogs ljon pa stug po'i 'khri shing. Palampur: Sungrab nyamso gyunpel parkhang.

Parkhang karchak: Zhuchen Tshul khrims rin chen. (1748) 1974. "gTsug lag khang chos 'byung bkra shis sgo mangs rten dang brten pa ji ltar bskrun pa las brtsams pa'i gleng ba bdud rtsi'i rlabs phreng." In The Collected Writings on Buddhist Philosophy, Liturgy, and Ritual of Zhuchen, edited by Jamyang Norbu, 7:127-195. New Delhi: Jamyang Norbu.

Sakar karchak: Zhu chen Tshul khrims rin chen. (1755) 1974. "Chos sde'i gtsug lag khang gzhan 'phrul mngon par gda' ba zhes bya ba bskrun pa las 'phros ba'i gleg baM kun dga'i 'dzum zer 'dzag pa'i zla gzhon.” In The Collected Writings on Buddhist Philosophy, Liturgy, and Ritual of Zhuchen, edited by Jamyang Norbu, 7:197-303. New Delhi: Jamyang Norbu.

Sakya kabum karchak: bKra shis lhun grub. 1736. "dPal sa skya'i rje btsun gong ma lnga'i gsung rab rin po che'i par gyi sgo 'phar 'byed pa'i karchak 'phrul gyi lde mig." In Sa skya bka' 'bum, vol. ba, f. 410r-475v. sDe dge dgon chen: sDe dge par khang.

Shebam chenmo: Anonymous. (17th c.) 1987. "She bam chen mo'i dper brjod." In Zhal lce phyogs bsdus, 117-190. Lhasa: Bod ljongs mi dmangs dpe skrun khang.

Situ rangnam: Si tu pạ chen. (1774) 1969. Ta'i si tur 'bod pa karma bstan pa'i nyin byed kyi rang tshul drangs por brjod dri bral shel gyi me long. New Delhi: Lokesh Chandra \& IAIC. 
Tengyur karchak: Zhuchen Tshul khrims rin chen. (1744) 1985. bsTan 'gyur dkar chag. Lhasa: Bod ljongs mi dmangs dpe skrun khang.

Zhuchen rangnam: Zhuchen Tshul khrims rin chen. (1774) 1971. "Chos smra ba'i bande tshul khrims rin chen du 'bod pa'i skye ba phal pa'i rkang 'thung dge sdig 'dres ma'i las kyi yal ga phan tshun du 'dzings par bde sdug gi lo 'dab dus kyi rgyal mos re mos su bsgyur ba." In The Autobiography of Tshul-Khrims-Rin-chen of sDe-dge, edited by N. Lungtok and N. Gyaltsan, 278-638. Delhi: N. Lungtok and N. Gyaltsan.

\section{$\underline{\text { Secondary Sources }}$}

Bell, Charles. 1928. The People of Tibet. Oxford: The Clarendon Press.

Booz, Patrick. 2011. "Tea, Trade and Transport in the Sino-Tibetan Borderlands." PhD diss., Faculty of Oriental Studies, Oxford University.

Boulnois, Lucette. 1983. Poudre d'or et monnaies d'argent au Tibet (principalement au XVIII ${ }^{e}$ siècle) [Gold powder and silver coins in Tibet (principally in the 18th century)]. Paris: CNRS.

Braudel, Fernand. 1986. Civilization and Capitalism, 15th-18th Century. Volume 2, The Wheels of Commerce. New York: Harper and Row.

Caumanns, Volker. 2013. "Paṇ chen Shākya mchog ldan's Monastic Seat Thub bstan gSer mdog can (Part I): The History of its Foundation." In Nepalica-Tibetica: Festgabe for Christoph Cüppers, edited by F.-K. Ehrhard and P. Maurer, 65-88. Halle: IITBS.

Chaix, Rémi. 2010. "Les aspects économiques de l'édition xylographique à l'imprimerie de sDe dge (I): La réalisation des blocs xylographiques sous le règne de bsTan pa tshe ring (1713/14-1738)." In Édition, éditions, edited by A. Chayet, C. Scherrer-Schaub, F. Robin, and J.-L. Achard, 85-113. München: Indus Verlag.

Chapela, Leonard. 1992. "Economic Institutions of Buddhist Tibet." Tibet Journal 17 (3): 2-40.

Col, Cynthia. 2009. "Picturing the Canon: The Murals, Sculpture and Architecture of the Derge Parkhang." PhD diss., Graduate Theological Union, Berkeley.

Cüppers, Christoph. 2010. "Some Remarks on Bka' 'gyur Production in 17th-century Tibet." In Édition, éditions, edited by A. Chayet, C. Scherrer-Schaub, F. Robin, and J.-L. Achard, 115-128. München: Indus Verlag.

Dung dkar Blo bzang 'phrin las (Dungkar Lobzang Trinlé). (1989) 1997. "Bod yig dpe rnying dpar skrun dang 'brel ba'i gnad don 'ga' zhig skor gleng ba." In Dung dkar blo bzang 'phrin las kyi gsung rtsom phyogs bsgrigs, 406-451. Zi ling: Krung go'i bod kyi shes rig dpe skrun khang. . 2016. "Tibetan Woodblock Printing: An Ancient Art and Craft." Translated by Tsering Dhundup Gonkatsang. Himalaya 36 (1): 163-177.

Feng Lin, He Xiaodong, Song Yan, and Wang Xiaoling. 2003. "Dege Yijingguan de jianzhu tese" [Architectural features of Dergé printing house]. Sichuan Wenwu 1: 56-61.

Goldstein, Melvyn. 1971. "Taxation and the Structure of a Tibetan Village." Central Asiatic Journal 15 (1): 1-27.

Karma rgyal mtshan (Karma Gyaltsen). 2000. "sDe dge par khang chos mdzod chen mo zhes bya ba rten dang brten pa ji ltar brtsams pa'i gleng ba." In Dege Yinjing Yuan [Dege SutraPrinting Academy], edited by Yang Jiamin, 38-47. Chengdu: Sichuan Renmin Chubanshe. 
Lha lung 'chi med rdo rje and Zla g.yang. 2009. Khams sde dge rgyal po'i srid don lo rgyus [A political history of the kings of Dergé (Kham)]. Beijing: Krung go'i bod rig pa dpe skrun khang.

Ramble, Charles, Peter Schwieger, and Alice Travers, eds. 2013. Tibetans Who Escaped the Historian's Net: Studies in the Social History of Tibetan-Speaking Societies. Kathmandu: Vajra Publications.

Rockhill, William. 1891. The Land of the Lamas: Notes of the Journey through China, Mongolia and Tibet. London: Longmans, Green and Co.

Surkhang, Wangchen Gelek. 1966. "Tax Measurement and lag 'don Tax." Bulletin of Tibetology 3 (1): $15-28$.

Tsarong, Paljor. 1998a. "Tseja: Structure and Economy of a Tibetan State Treasury." Tibet Journal 23 (3): 23-33.

- 1998b. "Economics of a Tibetan State Treasury: The Barley Supply Office." Tibet Journal 23 (2): 3-10.

Yang Jiamin, ed. 2000. Dege Yinjing Yuan [Dege Sutra-Printing Academy]. Chengdu: Sichuan Renmin Chubanshe. 